\title{
Accumulation-Exclusion Combined System for the DNA-Binding Harmful Chemicals with Insolubilized DNA
}

\author{
Shuya SATOH, Masanori Yamada, Motoyoshi NomizU, and Norio NiSHI ${ }^{\dagger}$ \\ Laboratory of Bio-Material Chemistry, Division of Bioscience, Graduate School of Environmental Earth Science, \\ Hokkaido University, Kita-10, Nishi-5, Kita-ku, Sapporo 060-0810, Japan
}

(Received May 13, 2003; Accepted September 5, 2003)

\begin{abstract}
DNA is not only the most important genetic material but a highly functional biomaterial. The unique structure of the double-stranded DNA causes its highly specific functions, such as intercalation, groove-binding and other molecular recognitions. Previously, we reported the preparation of insolubilized DNA by UV-irradiation. The UVirradiated DNA showed the potential utility as an accumulation device for harmful DNA-binding chemicals such as the dioxin-derivative. In this study, we investigated the exclusion process of accumulated chemicals from the insolubilized DNA, and extended this approach to the construction of an accumulation-exclusion combined system for DNA-binding harmful chemicals. Such a system would allow us to systematically concentrate very small amount of DNA-binding chemicals from large amounts of water. It might provide a suitable method to omit the complicated pre-treatment processes which are popular in the analysis for the highly diluted chemicals in the water system such as some environmental hormones. Two different procedures were performed to exclude ethidium bromide (EtBr) from UV-irradiated DNA containing EtBr. The first one is the treatment with a cationic polymer which would induce DNA-condensation and, as a result, exclude EtBr. Another one is the extraction of EtBr with organic solvent. The extraction process with an organic solvent attained a high exclusion efficiency for EtBr. The UV-irradiated DNA which accumulated the EtBr, could be easily recovered by washing with some organic solvents and maintain the efficiency to accumulate the DNA-binding chemicals.

\section{KEY WORDS DNA / UV-irradiation / Cross-Linking / Water-Insolubilization / Intercalation / Func-} tional Material / Endocrine Disruptor /
\end{abstract}

DNA is the most important genetic material for almost all living organisms. Double-stranded DNA has a unique structure consisting of a double helix and $\pi$ electron-rich base-pair stacking. ${ }^{1,2}$ The structure of the double-stranded DNA causes highly specific functions ${ }^{2}$ such as intercalation, groove-binding and other molecular recognition. Although such properties of DNA are very attractive as a functional material, its high watersolubility and biochemical instability have negated the practical utilization of DNA. Various trials to overcome these weak points have been carried out. Some approaches have already utilized DNA as a powerful tool and produced great successes. The DNA microarray technique ${ }^{3}$ is a good example using such special function of DNA. DNA-columns, DNA-gels, DNA-films, and a variety of DNA-containing composites ${ }^{4-17}$ have been prepared by covalent linking ${ }^{4-13}$ or conjugation with other polymers. ${ }^{14-17}$ DNA materials have shown their potential utility as chemosensory devices for DNA binding species. ${ }^{18}$ On the other hand, a trial to construct the accumulating system for specific compounds has been carried out. Some of the endocrine disruptors, mutagens, and carcinogenic chemicals have been known to show the affinity to the DNA structure. ${ }^{19}$ To accumulate such DNA-binding compounds, a large amount of DNA would be required because the adsorption capacity would play a key role.

Previously, we reported the preparation of a waterinsoluble DNA-film by UV-irradiation. ${ }^{6}$ The formation mechanism was estimated to be based on intermolecular multipoint cross-linking induced by radical formation. This method possesses some advantages. It enables us to immobilize DNA without any difficult processes and critical collapse of the doublestranded structure of DNA. This film was confirmed to be insoluble in water and resistant to degradation by nuclease. The UV-irradiated DNA has shown the potential utility as an accumulating device for pollutants. It could successfully accumulate DNA binding compounds such as the derivatives of polychlorinated biphenyl (PCB), dibenzo- $p$-dioxin (dioxin), and also benz[a]pyrene from their diluted aqueous solutions and also from multi-component solutions.?

In this study, we extended this approach to the exclusion process of accumulated pollutant. The studies on the exclusion process must be as valuable as that on the accumulation process, because the accumulationexclusion combined system would enable us to concentrate the very small amounts of DNA-binding pollutants from a large amount of water. Some analytical

${ }^{\dagger}$ To whom correspondence should be addressed (Phone/FAX: +81-11-706-2256, E-mail: nishin@ees.hokudai.ac.jp). 
techniques for highly diluted pollutant solutions require complicated pre-treatments. The combination of the accumulation method, based on the specific interaction between DNA and some compounds, and the exclusion process might provide a suitable way to omit such a complicated pre-treatment process.

In order to design an effective exclusion process of accumulated pollutant, we used ethidium bromide (EtBr) as a model compounds for the DNA-binding pollutants. EtBr has been exhaustively studied as a DNA-intercalative reagent and is also known to form a stable complex with double-stranded DNA. In this experiment, the DNA-immobilized beads were prepared using with UV-irradiation method. DNA-immobilized beads were treated with $\mathrm{EtBr}$ aqueous solution, and then two different procedures were performed to exclude EtBr from the UV-irradiated DNA containing EtBr. The first one is the treatment with cationic polymers which would induce DNA-condensation and, as a result, exclude EtBr. The other one is the extraction of EtBr with organic solvents.

\section{EXPERIMENTAL}

\section{Materials}

Double-stranded DNA (sodium salt from salmon milt, $M_{\mathrm{w}} ; c a .5 \times 10^{6}$ ) was purchased from Yuki Fine Chemical Co., Ltd., Tokyo, Japan. This DNA was used without further purification. Porous glass beads (approximately $\phi 1.0 \mathrm{~mm}$ ) were purchased from Tokyo Rikakikai Co., Ltd., Tokyo, Japan. 3-Aminopropyltriethoxysilane (APTES) was purchased from Sin-etsu Silicon Co., Ltd., Tokyo, Japan. Clupein (sulfate salt from herring milt, $M_{\mathrm{w}} ; 4111.9,4048.9,4137.9$ (Clupein-YI, -YII, -Z, respectively)), poly-L-lysine $\left(M_{\mathrm{w}} ; 1000-4000\right)$, and poly-L-glutamic acid $\left(M_{\mathrm{w}}\right.$; 4000-15000) were purchased from Wako Pure Chemical Industries, Ltd., Tokyo, Japan. They were used without further purification. The multimeric forms of the Try-Ile-Gly-Ser-Arg (multi-YIGSR) peptide, which has sixteen arginine residues $\left(M_{\mathrm{w}} ; 1.2 \times 10^{4}\right)$, was synthesized by a solid phase peptide synthesis with Fmocamino acid which was purchased from LKB Biochrom Ltd., Cambridge, England. Multi-YIGSR was used after the purification by HPLC. EtBr and all the other chemicals were reagent grade and purchased from Wako Pure Chemical Industries, Ltd., Tokyo, Japan.

\section{Preparation of DNA-Immobilized Beads}

The DNA-immobilized beads were prepared as previously described. ${ }^{6}$ Porous glass beads $(30 \mathrm{~g}$, approximately $\phi 1.0 \mathrm{~mm}$ ) were immersed into Piranha solution $\left(98 \% \mathrm{H}_{2} \mathrm{SO}_{4}: 30 \% \mathrm{H}_{2} \mathrm{O}_{2}=3: 1, \mathrm{v} / \mathrm{v}\right)$ for $30 \mathrm{~min}$ at $70^{\circ} \mathrm{C}$, then thoroughly rinsed with distilled water. The acid-treated beads were dried and reacted with $2 \%$ $(\mathrm{v} / \mathrm{v})$ APTES $/ n$-hexane solution for $2 \mathrm{~h}$ at room temperature. The propylamine-modified beads were dried after washing with $n$-hexane, ethanol and distilled water. The Double-stranded DNA was dissolved in distilled water and the concentration was spectrophotometrically determined using a UV-vis spectrophotometer (U-2000A, Hitachi Co., Ltd., Tokyo, Japan). The concentration of the DNA aqueous solution was adjusted to $10 \mathrm{mg} \mathrm{mL}^{-1}$. The DNA aqueous solution was applied onto the beads ( $10.0 \mathrm{mg}$ DNA for $1.0 \mathrm{~g}$ beads) and then dried at room temperature. UV-irradiation ( $254 \mathrm{~nm}, 5600 \mu \mathrm{W} \mathrm{cm}{ }^{-2}$ ) was carried out for $8 \mathrm{~h}$ using the UV light system (R-52G, Ultraviolet, Inc., U.S.). The UV-treated beads were repeatedly immersed in distilled water to remove soluble fraction of DNA, and the DNA-immobilized beads were dried and stored at room temperature. The amount of immobilized DNA was determined by the following procedure: The DNAimmobilized beads were treated with $1 \mathrm{M}$ hydrochloric acid solution at $100^{\circ} \mathrm{C}$ for $1 \mathrm{~h}$, and then the absorption of the supernatant was measured. The amount of immobilized DNA was calculated from the absorption at $260 \mathrm{~nm}$.

\section{Accumulation of Ethidium Bromide with UV-Irradiated $D N A$}

EtBr was dissolved in buffer solution $(10 \mathrm{mM}$ Tris$\mathrm{HCl}, 100 \mathrm{mM} \mathrm{NaCl}, \mathrm{pH}$ 7.4) to prepare the stock solution of $1 \mathrm{mM}$ EtBr. The DNA-immobilized beads $(100 \mathrm{mg})$ were immersed in an $\mathrm{EtBr}$ aqueous solution (1.0 mL, $50 \mu \mathrm{M}$ EtBr, $10 \mathrm{mM}$ Tris- $\mathrm{HCl}, 100 \mathrm{mM} \mathrm{NaCl}$ ) and incubated for $4 \mathrm{~h}$. The amounts of accumulated EtBr were spectrophotometrically determined from the absorption of the EtBr supernatant solution at $480 \mathrm{~nm}$ and $285 \mathrm{~nm}$.

\section{Exclusion of Ethidium Bromide from UV-Irradiated DNA}

For the following experiment, the DNA-immobilized beads $(100 \mathrm{mg})$ were immersed in the EtBr aqueous solution $(1.0 \mathrm{~mL}, 50 \mu \mathrm{M}$ EtBr, $10 \mathrm{mM}$ Tris- $\mathrm{HCl}, 100 \mathrm{mM}$ $\mathrm{NaCl}$ ) for $4 \mathrm{~h}$ as described above. The beads were removed from EtBr solution and rinsed with distilled water $(1.0 \mathrm{~mL} \times 3$ times). The exclusion experiment of EtBr from the UV-irradiated DNA was carried out by the two methods; the methods to use cationic polymers and organic solvents. In the exclusion process using cationic polymers, ability of three kinds of cationic polymers (poly-L-lysine, protamine, multiYIGSR) to exclude EtBr from the UV-irradiated DNA were evaluated. Poly-L-glutamic acid and $\mathrm{NaCl}$ were 
used as controls. These polymers were dissolved in a buffer solution $(10 \mathrm{mM}$ Tris- $\mathrm{HCl}, 100 \mathrm{mM} \mathrm{NaCl}$, $\mathrm{pH}$ 7.4) and the concentration was adjusted to an adequate value ([amino group] or [carboxyl group] $=3 \mathrm{mM}$ ). At three different molar ratios (amino residue: nucleotide $=0.1: 1,1: 1,3: 1$, the cationic polymer solutions $(1.0 \mathrm{~mL})$ were added to the DNA-immobilized beads $(100 \mathrm{mg})$ containing EtBr and incubated at room temperature. Poly-L-glutamic acid solution was used at the molar ratio of carboxylic acid residue: nucleoti$\mathrm{de}=1: 1$. The extent of the exclusion of EtBr was measured from the absorption of each supernatant solution at $480 \mathrm{~nm}$. The exclusion experiments using organic solvents were performed with four kinds of organic solvent (methanol, 1-butanol, acetonitrile, and hexane) and the methanol-hexane $(80: 20(\mathrm{w} / \mathrm{w}))$ mixed solvent. The organic solvents $(1.0 \mathrm{~mL})$ were added to the DNAimmobilized beads $(100 \mathrm{mg}$ ) containing $\mathrm{EtBr}$, and incubated at room temperature. The extent of the exclusion of $\mathrm{EtBr}$ was measured from the absorption spectra of the supernatant solution.

\section{Enrichment of Ethidium Bromide using UV-Irradiated DNA Column}

A diluted aqueous EtBr solution $(0.10 \mu \mathrm{M}, 1000 \mathrm{~mL})$ was buffered $(10 \mathrm{mM}$ Tris- $\mathrm{HCl}, 100 \mathrm{mM} \mathrm{NaCl})$ and adjusted $\mathrm{pH}$ to 7.4. The solution was passed through the column packed with DNA-immobilized beads $(7.0 \mathrm{~g})$ at a flow rate of $6 \mathrm{~mL} \mathrm{~min}^{-1}$ for $12 \mathrm{~h}$. The amounts of accumulated $\mathrm{EtBr}$ were spectrophotometrically determined from the absorption of the treated solution at $285 \mathrm{~nm}$. Desorption process was performed with batch elution method; DNA-immobilized beads containing $\mathrm{EtBr}$ were washed with distilled water $(10 \mathrm{~mL} \times 3$ times). Acetonitrile $(10-100 \mathrm{~mL})$ were added to the beads and incubated for $10 \mathrm{~min}$. The adsorption spectra of each supernatant solution were measured. Molar percent of the excluded $\mathrm{EtBr}$ and enrichment factor were determined. Here, enrichment factor was defined as follows; [enrichment factor $]=[$ EtBr concentration of eluent $] /[\mathrm{EtBr}$ concentration of initial solution].

\section{Reusability of UV-Irradiated DNA}

The reusability of the UV-irradiated DNA for the accumulation of $\mathrm{EtBr}$ after the exclusion processes of $\mathrm{EtBr}$ was evaluated. Prior to the reuse test, recovery of the used DNA-immobilized beads was performed. The beads treated with the cationic polymers $(100 \mathrm{mg}$ ) were immersed in $2 \mathrm{M} \mathrm{NaCl}$ for $30 \mathrm{~min}$ ( $3 \mathrm{~mL} \times 3$ times) to salt out the binding polymers and rinsed with distilled water $(3 \mathrm{~mL} \times 3$ times $)$. The beads treated with the organic solvents $(100 \mathrm{mg})$ were washed with ethanol $(3 \mathrm{~mL} \times 3$ times $)$ and dried. The recov-

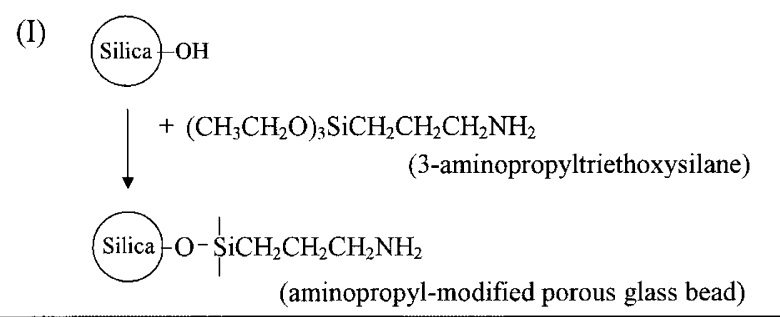
(II) Aminopropyl-modified porous glass
+ Double-stranded DNA solution $\left(10 \mathrm{mg} \mathrm{mL}^{-1}\right)$
Dry up (overnight at room temperature)
UV-irradiation $\left(254 \mathrm{~nm}, 5600 \mu \mathrm{W} \mathrm{cm}{ }^{-2}\right.$,for $8 \mathrm{~h}$ )
Rinsed with distilled water
DNA-immobilized beads

Figure 1. DNA-immobilization procedure onto the porous glass beads: (I) Modification of silanol groups on silica beads to aminopropyl-silica; (II) UV-irradiation to induce intermolecular cross-linking reaction of DNA.

ered DNA-immobilized beads were immersed again in $1.0 \mathrm{~mL}$ of aqueous EtBr solution $(50 \mu \mathrm{M})$ for $4 \mathrm{~h}$. The amounts of accumulated $\mathrm{EtBr}$ were determined as described above. These processes were repeated 5 times, and the decrease in the efficiency to accumulate $\mathrm{EtBr}$ was evaluated.

\section{RESULTS AND DISCUSSION}

\section{Preparation of DNA-Immobilized Glass Beads}

We have reported the method to prepare a waterinsoluble DNA-film by UV-irradiation. ${ }^{6}$ The formation mechanism for the water-insoluble DNA film was estimated to be based on the intermolecular multipoint cross-linking induced by the radical formation. The DNA-immobilized glass beads were prepared by the following procedure as shown in Figure 1: The doublestranded DNA solution $\left(10 \mathrm{~mL}, 10 \mathrm{mg} \mathrm{mL}^{-1}\right)$ was applied onto aminopropyl-modified porous glass beads $(10 \mathrm{~g})$ and dried, and then UV-irradiation $(254 \mathrm{~nm}$, $5600 \mu \mathrm{W} \mathrm{cm} \mathrm{cm}^{-2}$ ) was performed for $8 \mathrm{~h}$. The UVirradiated beads were rinsed with distilled water to remove the soluble fraction of DNA. The amounts of the eluted DNA and the immobilized DNA were spectrophotometrically determined. The amount of immobilized DNA was found to increase with the UVirradiation time, and the value reached an upper limit after about $8 \mathrm{~h}$ (data not shown). The amount of applied DNA was $10 \mathrm{mg}$ for $1 \mathrm{~g}$ of the beads, and approximately $80 \%$ of the applied DNA was immobilized.

As previously reported, the UV-irradiated DNA formed a three-dimensional polymer network structure. 


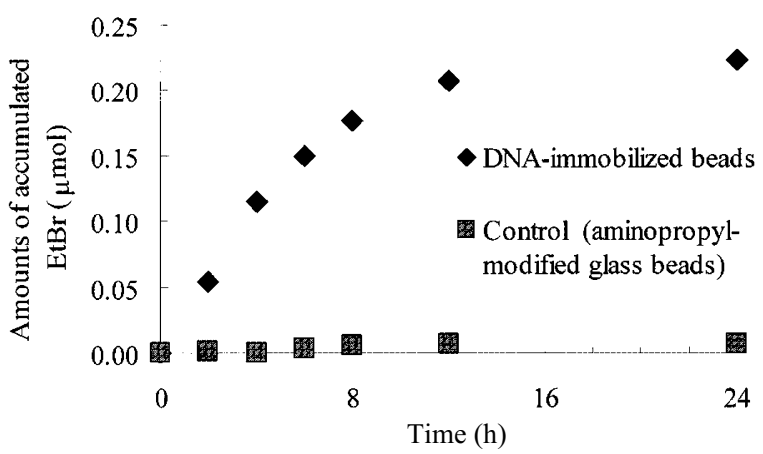

Figure 2. Accumulation of ethidium bromide by the DNAimmobilized beads.

The UV-irradiated DNA was water-insoluble and resistant to DNase. It was also found that most of the DNA molecules involved in the polymer network maintained the B-form structure and, as a result, the binding affinity to DNA-intercalative compounds was also maintained. In this study, all experiments were performed based on these characteristics.

\section{Efficiency of the Processes for Exclusion of EtBr from UV-Irradiated DNA}

In this study, we used $\mathrm{EtBr}$ as a model compound for the harmful DNA-intercalative compounds. $\mathrm{EtBr}$ has been well studied as a DNA-intercalative reagent and a useful probe to investigate the interactions with DNA. EtBr and the double-stranded DNA have been known to form a stable complex. The complex formation constant, $\mathrm{K}_{C}$, has been reported to be on the order of $10^{6} \mathrm{M}^{-1}$. The accumulation process and the exclusion processes of $\mathrm{EtBr}$ were performed in a batch experiment by the following procedure: The DNA-immobilized beads $(300 \mathrm{mg})$ were immersed in EtBr solution $(5.0 \mathrm{~mL}, 50 \mu \mathrm{M}$ EtBr, $10 \mathrm{mM}$ Tris- $\mathrm{HCl}$, $100 \mathrm{mM} \mathrm{NaCl}$ ) and the time course of the supernatant absorption was measured at $480 \mathrm{~nm}$ and $285 \mathrm{~nm}$. An increase of the amounts of accumulated $\mathrm{EtBr}$ could be seen in Figure 2, and the color of the DNA-beads changed from white to pink. The amounts of accumulated EtBr reached approximately $60 \%$ of the original contents of the solution. Under this condition, 1 molecule of EtBr corresponded to 15-20 pairs of the DNA bases. On the other hand, propylamine-modified glass beads without DNA hardly accumulated EtBr.

The UV-irradiated DNA showed the potential utility as an effective accumulating device for harmful DNA-intercalative compounds, such as polychlorinated biphenyl (PCB)-derivatives, dioxin-derivatives, benz[a]pyrene, etc. ${ }^{7}$ Considering the practical application of the UV-irradiated DNA, the exclusion process of such accumulated compounds must be as valuable as the accumulation process. The combina- tion of the accumulation and exclusion processes may have possibilities to concentrate and accumulate such DNA-binding compounds from the diluted solution or multi-component solution. The recycling of the DNAimmobilized beads may also become possible.

Two different procedures to exclude the accumulated compounds were performed. The first one was a process to use the DNA condensation effect of the cationic polymer. DNA condensation is known to be induced by neutralization of the highly negative charge density of the DNA molecule. Thermodynamic and spectroscopic studies have shown that the DNA condensation occur when approximately $85-90 \%$ of the phosphate groups of the DNA molecule are neutralized. ${ }^{20}$ The DNA-condensation is known to reduce the affinity between $\mathrm{EtBr}$ and DNA. Thus, it is expected that the complete exclusion of EtBr from the DNA structure would occur when sufficient amount of cationic polymer is added. Many varieties of DNA condensation agents have been known, such as protamine, spermine, histone, a cationic lipid ${ }^{21}$ and various synthetic cationic polymers. In this study, poly-L-lysine, protamine, multi-YIGSR, and poly-L-glutamic acid were chosen for this experiment. Poly-L-lysine is a linear polypeptide with basic lysine residues. Protamine is also a linear polypeptide with many arginine residues of which basicity is far stronger than the lysine residues. The protamines are basic peptides contained in the sperm of fishes, and they have a function to condense DNA molecules in the fish sperm. The protamine used in the present study is clupein obtained from herring sperm. Clupein is a mixture of three clupein species (clupein YI, YII, and Z) in which the arginine content is approximately $70 \%$. Multi-YIGSR is a synthetic dendrimer-type globular polypeptide which contains the cell adhesion peptide sequence of laminin, one of the cell adhesive proteins. It contains sixteen basic arginine residues together with acidic tyrosine residues and some neutral amino acid residues. Poly-L-glutamic acid is an acidic linear polypeptide and was chosen as a negative control. The concentration of each polymer solution was adjusted to the adequate molar ratio to the phosphate group of DNA ([charged residue of peptide]/[phosphate group of DNA] $=0.1,1.0,3.0$ ). To these different molar ratios, cationic polymer solutions were added to the DNA-immobilized beads containing EtBr. Since DNA was immobilized on a solid support, after the exclusion process, the components of the supernatant were the free $\mathrm{EtBr}$ and the extra cationic polymers. The percent of excluded $\mathrm{EtBr}$ was determined by the absorption of the supernatant after $8 \mathrm{~h}$ as shown in Figure 3. The exclusion efficiency was found to be dependent on the molar ratio. As the 


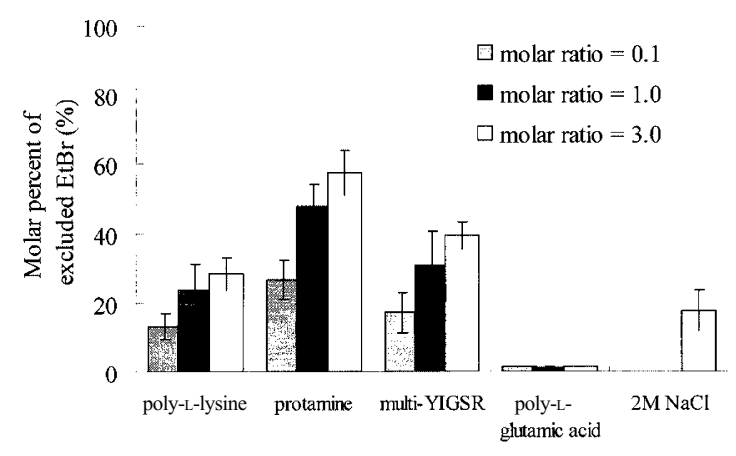

Figure 3. Effect of cationic polymer on the exclusion of ethidium bromide from the UV-irradiated DNA. Vertical axis indicates molar percent of excluded $\mathrm{EtBr}$ with respect to accumulated one.

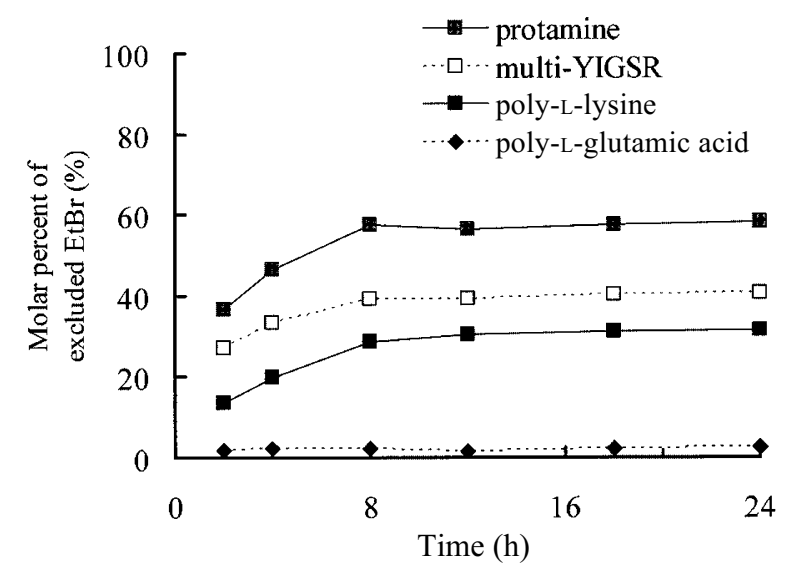

Figure 4. Exclusion of ethidium bromide from the UVirradiated DNA by the treatment with cationic polymers. The molar ratio ([charged residue of peptide] / [phosphate group of DNA]) was fixed at 3.0. Vertical axis indicates molar percent of excluded EtBr with respect to accumulated one.

molar ratio increases from 0.1 to 3.0 , the amounts of excluded $\mathrm{EtBr}$ increased. $\mathrm{NaCl}$ solution showed not so high exclusion efficiency, and the molar percent of excluded EtBr with respect to the amount of accumulated $\mathrm{EtBr}$ was around $20 \%$. In the following experiment, the molar ratio was fixed at 3.0 and the effect of processing time was evaluated. In Figure 4, molar percent of excluded EtBr with respect to the amount of accumulated $\mathrm{EtBr}$ was plotted $v s$. the processing time. The maximum exclusion was found to be attained in $8 \mathrm{~h}$. In all cases, protamine was more effective than the other polymers. The strongly basic arginine residues in the protamine molecules seem to be very effective. Molar percent of excluded EtBr with respect to the amount of accumulated $\mathrm{EtBr}$ reached approximately $60 \%$. On the other hand, poly-L-glutamic acid never showed any effects. Immobilized DNA has been UV-irradiated and formed a polymer network structure, which would cause a not so high efficiency of cationic polymers on the condensation of DNA, and also the exclusion of EtBr. However, such well-known interactions for DNA were found to be retained even on the

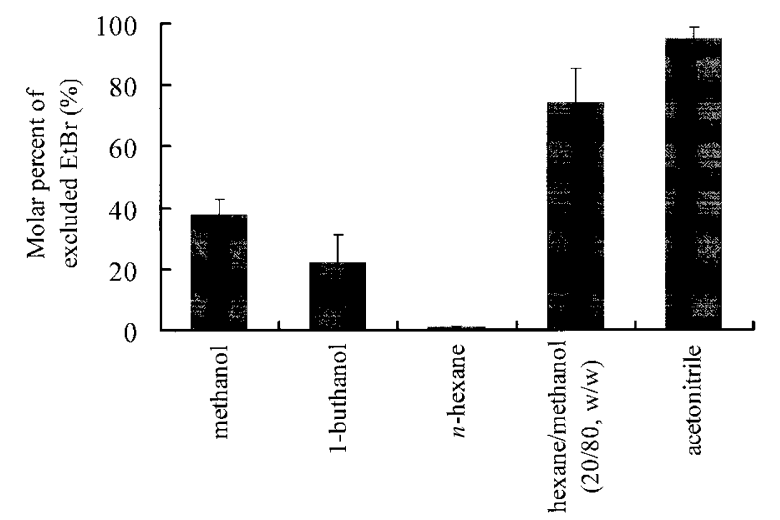

Figure 5. Exclusion of ethidium bromide from the UVirradiated DNA by the treatment with organic solvents. Vertical axis indicates molar percent of excluded $\mathrm{EtBr}$ with respect to accumulated one.

UV-irradiated DNA. This phenomenon may provide a possibility for the utilization of the UV-irradiated DNA.

Another exclusion process was to use the extraction technique with organic solvents. Intercalative reagents are known to bind DNA through the interaction between the hydrophobic planar materials and the DNA base pairs. Thus, a simple extraction technique by organic solvents was expected to be effective for the exclusion of EtBr from the UV-irradiated DNA. In this study, methanol, 1-buthanol, hexane, acetonitrile, and the mixture of methanol-hexane $(80: 20(\mathrm{w} / \mathrm{w}))$ were chosen for the following experiments.

Each solvent was added to the DNA-immobilized beads containing EtBr. The percentage of excluded $\mathrm{EtBr}$ was determined by the absorption of the supernatant solution after $1 \mathrm{~h}$ as shown in Figure 5. Acetonitrile and the mixture of methanol-hexane (80:20 $(w / w))$ showed the high efficiency for the extraction of EtBr from the DNA-immobilized beads which are wet with water. The mixture of methanol-hexane (80:20 $(\mathrm{w} / \mathrm{w}))$ showed a higher efficiency than methanol and hexane. Hexane showed no effects, and similar results were obtained in the extraction processes using benzene and other non-polar solvents in the exclusion experiment for $\mathrm{EtBr}$ (data not shown). In contrast, hexane was shown to be a very appropriate solvent for the extraction of non-polar intercalative reagents such as dioxin-derivatives and benz[a]pyrene. These different results were interpreted by the difference in the polarity of each compound. The extraction of hydrophilic compounds, such as EtBr, would be difficult when nonpolar solvents are used. The good results obtained by acetonitrile and the methanol-hexane mixture would be attributed to their adequate hydrophilic-hydrophobic balance. The control of the polarity of solvents would be required for the effective extraction of the various intercalative compounds. 
Table I. Enrichment of ethidium bromide by DNA-immobilized beads column

\begin{tabular}{cccccccc}
\hline $\begin{array}{c}\text { beads } \\
(\mathrm{g})\end{array}$ & $\begin{array}{c}\text { DNA } \\
(\mathrm{mg})\end{array}$ & $\begin{array}{c}\text { time } \\
(\mathrm{h})\end{array}$ & $\begin{array}{c}\text { adsorption } \\
(\mu \mathrm{mol})\end{array}$ & eluent(volume $)$ & $\begin{array}{c}\text { desorption } \\
(\mu \mathrm{mol})\end{array}$ & $\begin{array}{c}\text { exclusion rate } \\
(\%)\end{array}$ & enrichment factor \\
\hline 7.0 & 53.9 & 12 & $0.078 \pm 0.002$ & $\mathrm{CH}_{3} \mathrm{CN}(15 \mathrm{~mL})$ & $0.076 \pm 0.001$ & $97.5 \pm 1.0$ & $50 \pm 0.2$ \\
7.0 & 53.9 & 12 & $0.081 \pm 0.002$ & $\mathrm{CH}_{3} \mathrm{CN}(104 \mathrm{~mL})$ & $0.078 \pm 0.002$ & $97.2 \pm 2.2$ & $7.3 \pm 0.3$ \\
\hline
\end{tabular}

\section{Enrichment of Ethidium Bromide using UV-Irradiated} DNA Column

Very diluted $\mathrm{EtBr}$ aqueous solution $(0.10 \mu \mathrm{M}$, $1000 \mathrm{~mL}$ ) was passed through the column packed with DNA-immobilized beads $(7.0 \mathrm{~g})$ at a flow rate of $6 \mathrm{~mL} \mathrm{~min}{ }^{-1}$ for $12 \mathrm{~h}$. Then approximately $80 \%$ of $\mathrm{EtBr}$ with respect to the contents of the original solution were accumulated. Desorption process was performed with batch elution method. In order to enrich ethidium bromide, relatively small amount of acetonitrile (10$100 \mathrm{~mL}$ ) was added to DNA-immobilized beads containing EtBr. Under the adequate condition, the eluate contained nearly $100 \%$ of accumulated $\mathrm{EtBr}$ and enrichment factor reached to 50 (Table I).

\section{Evaluation of the Reuse of Used UV-Irradiated DNA}

The reuse of the used UV-irradiated DNA was evaluated based on the recycling of this material. As described above, the accumulated EtBr could be excluded from DNA by two different procedures. In the case of the exclusion process using a cationic polymer, it would require a recovery process to reuse the UV-irradiated DNA. Cationic polymers and DNA have been known to form a polyelectrolyte complex (PEC) by electrostatic interaction. PEC could be dissociated by changing the $\mathrm{pH}$ or by the addition of a low molecular weight electrolyte. $^{22}$ The used DNA-immobilized beads, which were treated with protamine, could be recovered by immersing them in $2 \mathrm{M} \mathrm{NaCl}$ for $30 \mathrm{~min}$ ( 3 times), followed by a rinse with distilled water and drying. In the case of the exclusion process using an organic solvent, the DNA-immobilized beads were rinsed with ethanol and dried to recover them. After these processes, the recovered DNA-immobilized beads were examined repeatedly in a batch experiment, as described above.

The efficiencies of the DNA-immobilized beads in the accumulation of EtBr were expressed by the comparison of the amount of accumulated $\mathrm{EtBr}$ for the batch of the virgin beads and of the used beads as shown in Figure 6. The DNA-immobilized beads, which were treated with a cationic polymer, decreased in its efficiency to accumulate EtBr for each use. This would be caused by the incomplete procedure of dissociation and washing out of the cationic polymer. In contrast, the DNA-immobilized beads, which were treated with organic solvents, constantly maintained the efficiency. Considering the high efficiency of acetonitrile, the pro-

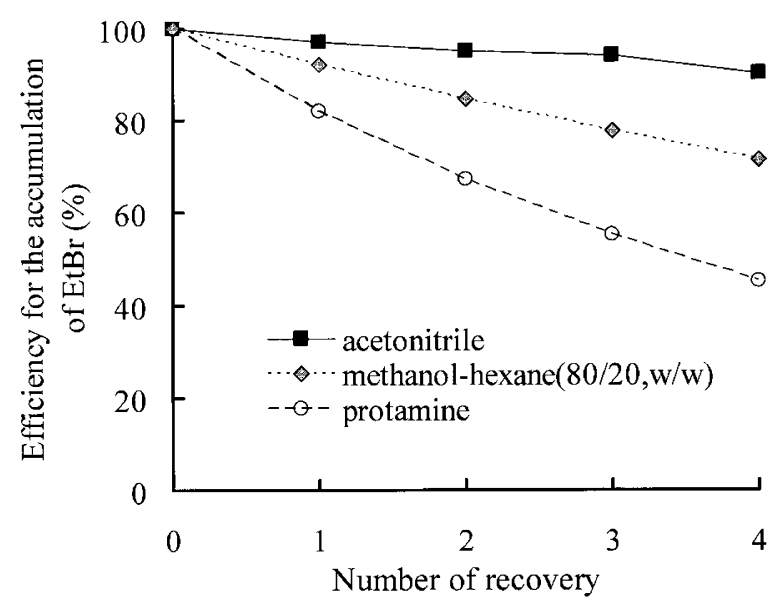

Figure 6. Comparison of each exclusion process to reuse the UV-irradiated DNA.

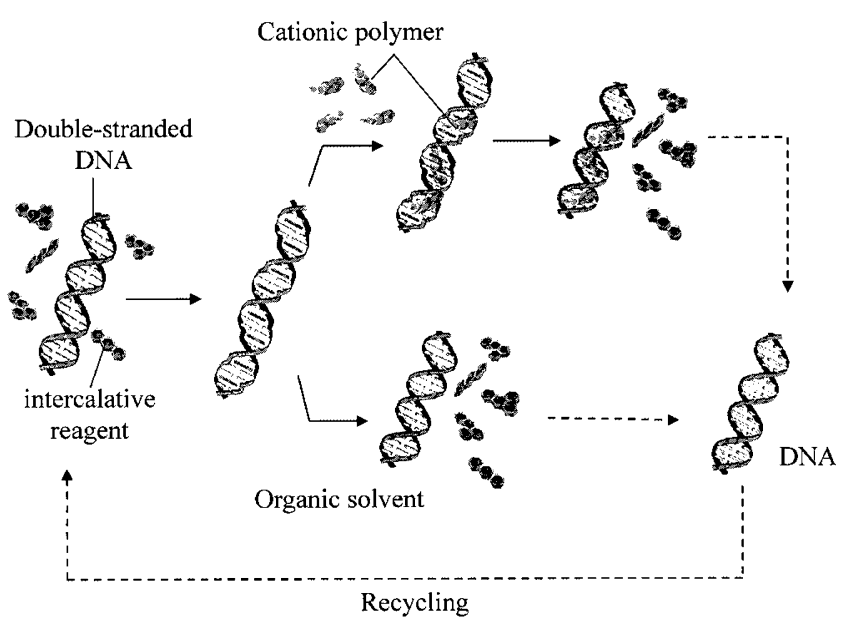

Figure 7. A schematic drawing for the accumulation-exclusion combined system.

cedure to employ this solvent would be the best as the accumulation-exclusion combined system for EtBr. A schematic drawing for the accumulation-exclusion combined system is shown in Figure 7. These possibilities would encourage the utilization of DNA as the device for other affinity separations.

\section{CONCLUSIONS}

We proposed the construction of an accumulationexclusion combined system for the DNA-binding of harmful chemicals. Insolubilized double-stranded DNA was easily prepared by UV-irradiation. The UV-irradiated DNA maintained the B-form structure and accumulated some DNA-binding chemicals from 
highly diluted aqueous solutions or multi-component solutions. The accumulated chemicals could be excluded by some procedure, such as DNA-condensation which is induced by a cationic polymer and the extraction process with organic solvents which have the appropriate polarity. Especially, a high efficiency and reusability were attained by the extraction process with some organic solvents. These results suggest that the UV-irradiated DNA has the potential utility as a useful tool for the selective condensation of a very small amount of chemicals from highly diluted solutions. It might provide a suitable method to replace the complicated pre-treatment processes which are employed in the analytical techniques for highly diluted chemicals such as the dioxin-derivatives.

Acknowledgments. This work was supported by the Grants-in-Aid for Scientific Research from the Ministry of Education, Culture, Sports, Science and Technology of Japan (No. 11694114, No. 11450359, No. 10555327, No. 113132201, and No. 14350491) and also the Hokkaido Foundation for the Promotion of Scientific and Industrial Technology (Hokscitec).

\section{REFERENCES}

1. J. D. Watson and F. H. Click, Nature, 171, 737 (1953).

2. W. Saenger, "Principles of Nucleic Acid Structure", SpringerVerlag GmbH \& Co., Berlin, 1987.

3. S. P. A. Foder, R. P. Rava, X. C. Huang, A. C. Pease, C. P. Holmes, and C. L. Adams, Nature, 364, 555 (1993).

4. R. M. Litman, J. Biol. Chem., 44, 6222 (1968).
5. M. Yamada, K. Kato, K. Shindo, M. Nomizu, M. Haruki, N. Sakairi, K. Ohkawa, H. Yamamoto, and N. Nishi, Biomaterials, 22, 3121 (2001).

6. M. Yamada, K. Kato, M. Nomizu, N. Sakairi, K. Ohkawa, H. Yamamoto, and N. Nishi, Chem. Eur. J., 8, 1407 (2002).

7. M. Yamada, K. Kato, M. Nomizu, K. Ohkawa, H. Yamamoto, and N. Nishi, Environ. Sci. Technol., 36, 949 (2002).

8. D. Umeno, T. Kano, and M. Maeda, Anal. Chim. Acta., 365, 101 (1998).

9. M. Burgener, M. Sanger, and U. Candrian, Bioconjug. Chem., 11, 749 (2000).

10. J. P. Coarec, N. Deligianis, J. R. Martin, I. Lawrence, E. Souteyrand, C. Polychronakos, and M. F. Lawrence, Biosens. Bioelectron., 17, 405 (2002).

11. P. T. Gilham, J. Am. Chem. Soc., 84, 1311 (1962).

12. D. Rickwood, Biochim. Biophys. Acta., 269, 47 (1972).

13. H. Kawaguchi, A. Asai, Y. Ohtsuka, H. Watanabe, T. Wada, and H. Handa, Nucleic Acids Res., 17, 6229 (1989).

14. E. T. Bolton and B. J. MacCarthy, Proc. Natl. Acad. Sci. U.S.A., 48, 1390 (1962).

15. K. Tanaka and Y. Okahata, J. Am. Chem. Soc., 118, 10679 (1996).

16. K. Iwata, T. Sawadaishi, S. Nishimura, S. Tokura, and N. Nishi, Int. J. Biol. Macromol., 18, 149 (1996).

17. H. Kitamura, E. Matsuura, A. Nagata, N. Sakairi, S. Tokura, and N. Nishi, Int. J. Biol. Macromol., 20, 75 (1997).

18. E. Palecek, R. Kizek, L. Havran, S. Billova, and M. Fojta, Anal. Chim. Acta., 469, 73 (2002).

19. E. C. Miller and J. A. Miller, Cancer, 47, 2275 (1987).

20. J. Dufourcq, W. Neri, and N. Henry-Toulme, FEBS Lett., 421, 7 (1998).

21. A. J. Geall, M. A. W. Eaton, T. Baker, C. Catterall, and I. S. Blagbrough, FEBS Lett., 459, 337 (1999).

22. V. A. Izumrudov and M. V. Zhiryakova, Macromol. Chem. Phys., 200, 2533 (1999). 